A major purpose of the Technical Information Center is to provide the broadest dissemination possible of information contained in DOE's Research and Development Reports to business, industry, the academic community, and federal, state and local governments.

Although a small portion of this report is not reproducible, it is being made available to expedite the availability of information on the research discussed herein. 
ORNL/RA.SA- $-87 / 35$

DE $90 \quad 002130$

ORNL/RASA-87/35

HEALTH AND SAFETY RESEARC.H DiVISION

Nuclear and Chemical Waste Programs

(Activity No. AH 100500 0; ONLWC01)

\title{
RESULTS OF THE RADIOLOGICAL SURVEY AT 24 LONG VALLEY ROAD, LODI, NEW JERSEY (LJ048)
}

W. D. Cottrell, L. M. Floyd, M. W. Francis, and J. O. Mynatt

Date Published - August 1989

Investigation Team

R. E. Swaja - Measurement Applications and Development Manager

W. D. Cottrell - FUSRAP Project Director

R. W. Doane - Field Survey Supervisor

\author{
Survey Team Members \\ A. C. Butler \\ B. S. Ellis \\ K. S. Dickerson \\ D. W. Greene \\ D. S. Foster \\ C. A. Mubr \\ R. A. Mathis \\ W. H. Shinoaugh" \\ E. M. Pilz \\ 'N. Winton
}

-Former Employees of Marin Marietta Energy Systems, Inc.

'Stone Associates

Work performed by the MEASUREMENT APPLICATIONS AND DEVELOPMENT GROUP

Prepared by the OAK RIDGE NATIONAL LABORATORY

Out Ridpe. Tenoewec 37831.6285 speraced by

MARTIN MARIETTA ENERGY SYSTEMS. INC for the

U.S. DEPARTMENT OF ENERGY

under Contract No. DE-ACOS-84OR 21400 


\section{CONTENTS}

LIST OF FIGURES $\ldots \ldots \ldots \ldots \ldots \ldots \ldots \ldots$

LIST OF TABLES $\ldots \ldots \ldots \ldots \ldots \ldots \ldots \ldots \ldots$

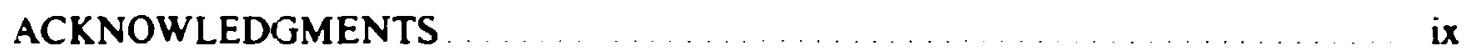

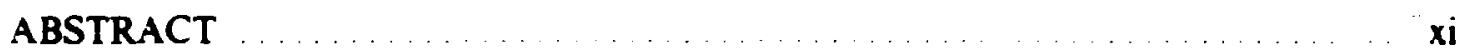

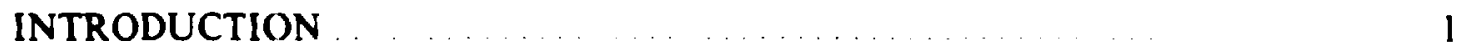

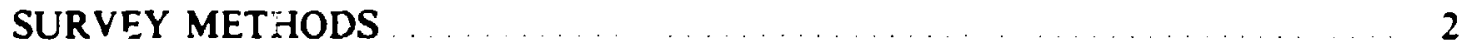

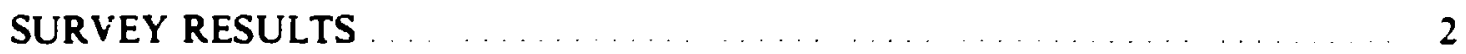

Surface Gamma Radiation Levels $\ldots \ldots \ldots \ldots \ldots$

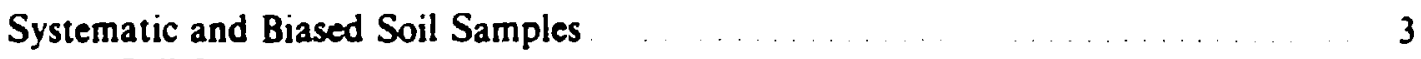

Auger Soil Samples $\quad \ldots \ldots \ldots \ldots \ldots \ldots \ldots$

SIGNIFICANCE OF FINDINGS $\ldots \ldots \ldots \ldots \ldots \ldots$

REFERENCES . 


\section{LIST OF FIGURES}

I Gamma radiation levels $(\mu \mathrm{R} / \mathrm{h})$ measured on the surface at 24 Long Valley Road, Lodi, New Jersey (LJ048)

2 Diagram showing locations of soil samples taken at 24 Long Valley Road, Lodi, New Jersey (LJ048)

3 Gamma profile for auger 'ole 1 (LJ048A !) at 24 Long Valley Road, Lodi, New Jersey

4 Gamma profile for auger hole 2 (LJ048A2) at 24 Long Valley Road, Lodi, New Jersey

5 Gamma profile for auger hole 3 (LJ048A3) at 24 Long Valley Road, Lodi, New Jersey

6 Gamma profile for auger hole 4 (LJ048A4) at 24 Long Valley Road, Lodi, New Jersey

7 Gamma profile for auger hole 5 (LJ048A5) at 24 Long Valley Road, Lodi, New Jersey

8 Gamma profile for auger hole 6 (LJ048A6) at 24 Long Valley Road, Lodi. New Jersey 


\section{LIST OF TABLES}

1 Applicable guidelines for protection against radiation

2 Background radiation levels for the northern PJew Jersey area

3 Concentrations of radionuclides in soil at 24 Long Valley Road, Lodi, New Jersey (LJ048) 


\section{ACKNOWLEDGMENTS}

Research for this project was sponsored by the Division of Facility and Site Decommissioning Projects, U.S. Department of Energy, under Contract No. DEAC05-840R21400 with Martin Marietta Energy Systems, Inc. The authors wish to ack. nowledge the support of J. E. Baublitz, Acting Director, Office of Remedial Action and Waste Technology; J. J. Fiore, Director, Division of Facility and Site Decommissioring Projects; and members of their staffs. The authors also appreciate the contributions of J. L. Rich, S. W. Hawthorne, B. C. Littleton, and L. J. Jeffers of the Publications Division: M. S. Uziel of the Environmental Information Systems Group; D. A. Robens, and T. R. Stewart of the Measurement Applications and Development Group; A. C. Butler and B. S. Ellis forıner employees of Martin Marietta Energy Systems, Inc.; and W. H. Shinpaugh of Don Stone Associates for participation in the coilection, analyses, editing, and reporting of data for this survey. 


\begin{abstract}
Maywood Chemical Works (MCW) of Maywood, New Jersey, generated process wastes and residues associated with the production and refining of thorium and thorium compounds from monazite ores from 1916 to 1956 . MCW supplied rare earth metals and thorium compounds to the Atomic Energy Commission and various other government agencies from the late 1940 s to the mid-1950s. Area residents used the sandlike waste from this thorium extraction process mixed with tea and cocoa leaves as mulch in their yards. Some of these contaminated wastes were also eroded from the site into Lodi Brook. At the request of the U.S. Department of Energy (DOE), a group from Oak Ridge National Laboratory conducts investigative radiological surveys of properties in the vicinity of $M C W$ to determine whether a property is contaminated with radioactive residues, principally ${ }^{232} \mathrm{Th}$, derived from the MCW site. The survey typically includes direct measurement of gamma radiation levels and soil sampling for radionuclide analyses. The survey of this site, 24 Long Valley Road, Lodi, New Jersey (LJ048), was conducted during 1985 and 1986.
\end{abstract}

Results of the survey demonstrated radionuclide concentrations in excess of the DOE Formerly Utilized Sites Remedial Action Program criteria. The radionuclide distributions are typical of the type of material originating from the MCW site. 


\section{RESULTS OF THE RADIOLOGICAL SLRVEY AT 24 LONG VALLEY ROAD, LODI, NEW JERSEY (LJ048)*}

\section{INTRODUCTION}

From 1916 to 1956, process wastes and residues associated with the production and refining of thorium and thorium compounds from monazite ores were generated by the Maywood Chemical Works (MCW), Maywood, New Jersey. During the latter part of this period, MCW supplied rare earth metals and thorium compounds to various government agencies. In the 1940s and 1950s, MCW produced thorium and lithium, under contract, for the Atomic Energy Commission (AEC). These activities ceased in 1956, and, approximately three years later, the 30-acre real estate was purchased by the Stepan Company. The property is located at 100 Hunter Avenue in a highly developed area in Maywood and Rochelle Park, Bergen County, New Jersey.

During the early years of operation, MCW stored wastes and residues in lowlying areas west of the processing facilities. In the early 1930s, these areas were separated from the rest of the property by the construction of New Jersey State Highway 17 . The Stepan property, the interim storage facility, and several vicinity properties have been designated for remedial action by the U.S. Department of Energy (DOE).

The waste produced by the thorium extraction process was a sandlike material containing residual amounts of thorium and its decay products, with smaller quantities of uranium and its decay products. During the years 1928 and 1944 to 1946 , area residents used these process wastes mixed with tea and cocoa leaves as mulch in their lawns and gardens. In addition, some of the contaminated wastes were apparently eroded from the site into Lodi Brook and carried downstream.

Lodi Broo'. is a small stream flowing south from Maywood with its headwaters near the jtepan waste storage site. Approximately $150 \mathrm{ft}$ after passing under State Route 17, the stream has been diverted underground through concrete or steel culverts until it merges with the Saddle River in Lodi, New Jersey. Only a small section near Interstate 80 remains uncovered. From the 1940 s to the 1970 s when the stream was being diverted underground, its course was altered several times. Some of these changes resulted in the movement of contaminated soil to the surface of a few properties, where it is still in evidence. In other instances, the

\footnotetext{
-The survey was performed by members of the Measurement Applications and Development Group of the Health and Safety Research Division at Oak Ridge Nationai Laboratory under U.S. DOE contract DE.AC05-840R 21400 .
} 
contaminated soil was covered over or mixed with clean fill, leaving no immediate evidence on the surface. Therefore. properties in question may be drilled in search of former streambed material. even in the absence of surface contamination.

As a result of the Energy and Water Appropriations Act of Fiscal Year 1984, the property discussed in this report and properties in its vicinity contaminated with residues from the former $\mathrm{MCW}$ were included as a decontamination research and development project under the DOE Formerly Utilized Sites Remedial Action Program. As part of this project, DOE is conducting radiological surveys in the vicinity of the site to identify properties contaminated with residues derived from the $\mathrm{MCW}$. The principal radionuclide of concern is thorium-232. The radiological surveys discussed in this report are part of that effort and were conducted, at the request of DOE, by members of the Measurement Applications and Development Group of the Oak Ridge National Laboratory.

A radiological survey of the private, residential property at 24 Long Valley Road, Lodi, New Jersey, was conducted during 1985 and 1986. The survey and sampling of the ground surface was carried out on October 23, 1985, and the follow-up subsurface investigation $x$ as performed on September 17, 1986.

\section{SURVEY METHODS}

The radiological survey of the property included: (1) a gamma scan of the entire property outdoors, (2) collection of surface and subsurface soil samples, and (3) gamma profiles of auger holes. No indoor survey measurements were pcrformed.

Using a portable gamma scintillation meter, ranges of measurements were recorded for areas of the property surface. If the gamma exposure rates were elevated, a biased soil sample was taken at the point showing the highest gamma radiation level. Systematic soil samples were taken at various locations on the property, irrespective of gamina radiation levels. These survey methods followed the plan outlined in Reference 1.

To definc the extent of possible subsurface soil contamination, the auger holes were drilled to depths of approximately $2 \mathrm{~m}_{\text {. }}$. A plastic pipe was placed in each hole, and a $\mathrm{NaI}$ scintillation probe was lowered inside the pipe. The probe was encased in a lead shield with a horizontal row of collimating slits on the side. This collimation allows measurement of gamma radiation :...cnsities resulting. from contamination within small fractions of the hole depth. Measurements were usually made at ,5- or $30-\mathrm{cm}$ intervals. If the gamma readings in the hole were elevated, a soil sample was scraped from the wall of the auger hole at the point showing the highest gamma radiation level. The auger hole toggings were used to select locations where further soil sampling would be useful. A split-spoon sampler was used to collect subsurface sampies at known depths. In some auger holes, a combination of split-spoon sampling ant side-wail scraping was used to collect samples. A comprehensive description of the survey methods and instrumentation has been presented in another report. ${ }^{2}$

\section{SURVEY RESULTS}

Applicable federal guidelines are summarized in Table $1 .^{3}$ The normal background radiation levels for the not thern New Jersey area are presented in Table 2." These data 
are provided for comparison with survey results presented in this section. All direct measurement results presented in this report are gross readings; buckgruund radiation levels have not been subtracted. Similarly, background concentrations have not been subtracted from radionuclide concentrations measured in environmental samples.

\section{Surface Gamma Radiation Levels}

Gamma radiation levels measured during a gamma scan of the surface of the property are given in Fig. 1. Gamma exposure iates over the major portion of the property ranged from 5 to $15 \mu R / h$. The area between the property line and the north side of the house measured 11 to $26 \mu R / h$. Gamma levels in the backyard ranged from 6 io $15 \mu R / h$. One area in the front yard ranged from 26 to $32 \mu R / h$. Some areas with elevated gamma levels are indicated by crosshatching in Fig. 1.

\section{Systematic and Binsed Soil Samples}

Systematic and biased soil samples were taken from various locations on the property for radionuclide analyses. Locations of the systematic (S) and biased (B) samples are shown in Fig. 2, with results of laboratory analyses provided in Table 3. Concentrations of radionuclides in the systematic samples were all within normal background levels for the northern New Jersey area (Table 2). Concentrations of ${ }^{226} \mathrm{Ra}$, ${ }^{232} \mathrm{Th}$, and ${ }^{238} \mathrm{U}$ in biased samples ranged from 0.63-5.7 $\mathrm{pCi} / \mathrm{g}, \mathrm{i} .3-57 \mathrm{pCi} / \mathrm{g}$, and $0.82-7.8 \mathrm{pCi} / \mathrm{g}$, respectively. Of four locations from which biased samples were collected, B1 and B2 had concentrations of ${ }^{226} \mathrm{Ra}$ and/or ${ }^{232} \mathrm{Th}$ in excess of DOE guidelines (Table 1), and the remaining two (B3 and B4) showed combined concentrations of ${ }^{232} \mathrm{Th}$ and ${ }^{226} \mathrm{Ra}$ approaching guideline values.

\section{Auger Soil Samples}

Varying thicknesses of subsuriace soil were sampled from depths of 0 to $185 \mathrm{~cm}$ in auger (A) holes which were drilled at 6 separate locations indicated in Fig. 2. The results of anal; ses of :hese samples are given in Table 3 . Concentrations of ${ }^{226} \mathrm{Ra}$ and ${ }^{232} \mathrm{Th}$ in soll samples from all auger holes ranged from 0.54 to 3.1 and 0.74 to $25 \mathrm{pCi} / \mathrm{g}$, respec. tively. Radionuclide concentrations in excess of DOE criteria (Table 1) were found in holes A4 and A6. Soil samples from auger hole A6 had concentrations of ${ }^{232} \mathrm{Th}$ as high as $25 \mathrm{pCi} / \mathrm{g}$ at a depth of $1.65 \mathrm{~m}$. This location appeared to coincide with the original loca. tion of Lodi Brook before it was ielocated and enclosed in a culvert.

Gamma logging was performed in each of the 6 auger holes to characterize and further define the extent of possible contamination. The logging technique used here is not radionuclide specific. However, logging data, in conjunction with soil analyses data, may be used to estimate regions of elevated radionuclide concentrations in auger holes when compared with background levels for the area. Following a comparison of these data, it appears that any shielded scintillator readings of $1000 \mathrm{cpm}$ or greater generally indicate the presence of eievated concentrations of ${ }^{226} \mathrm{Ra}$ and/or ${ }^{232} \mathrm{Th}$. Data from the gamma profiles of the logged auger holes are graphically rep.esented in Fig. 3 through Fig. 8. The maximum reading in auger hole 1 was $1051 \mathrm{cpm}$ at $0.2 \mathrm{~m}$. Loggings in auger hole 2 were elevated from 0.8 to $1.5 \mathrm{~m}$, with a maximum of $2695 \mathrm{cpm}$ at $1.2 \mathrm{~m}$. 
Readings in hole 3 were slightly elevated from 0.2 to $0.3 \mathrm{~m}$. with a maximum of $1291 \mathrm{cpm}$ at $0.2 \mathrm{~m}$. In hole 4 , elevated readings existed from the surface to $0.3 \mathrm{~m}$, with a inaximum of $1595 \mathrm{cpm}$ at $0.2 \mathrm{~m}$. Loggings for hole 5 were slightly elevated from the surface to $0.2 \mathrm{~m}$, with a maximum of $1112 \mathrm{cpm}$ at $0.2 \mathrm{~m}$. Readings in hole 6 were elevated from 1.1 to the maximum depth drilled $(1.8 \mathrm{~m})$, with a maximum of $5157 \mathrm{cpm}$ at $1.5 \mathrm{~m}$.

\section{SIGNIFICANCE OF FINDINGS}

Measurements taken at 24 Long Valley Road indicate that the property contained radioactive contamination primarily from the ${ }^{232} \mathrm{Th}$ decay chain with some contamination from the ${ }^{238} \mathrm{U}$ decay chain. These radionuclide distributions are typical of the type of material originating from the processing operations at the MCW site. The concentration and extent of ${ }^{232} \mathrm{Th}$ on this property is in excess of applicable DOE criteria. The greatest concentration of this material was found at sample locations B1, B2, A2, A4, and A6 (Fig. 2). Based on the results of this radiological assessment, it is recommended that this site be considered for inclusion in the DOE remedial action program.

\section{REFERENCES}

1. W. D. Cottrell, ORNL, to A. J. Whitman, DOE/HQ, correspondence, "Radiological Survey of Private Properties in Lodi, New Jersey " (August 15, 1984).

2. T. E. Myrick, B. A. Berven, W. D. Cottrell, W. A. Goldsmith, and F. F. Haywood, Procedures Manual for the ORNL Radiological Survey Activities (RASA) Program, Oak Ridge National Latoratory, ORNL/TM-8600 (April 1987).

3. U.S. Department of Energy, Guidelines for Residual Radioactive Material at Formerly Utilized Sites, Remedial Action Program and Remote Surplus Facilities Management Program Sites (Rev. 2, March 1987).

4. T. E. Myrick, B. A. Berven, and F. F. Haywood, State Background Radiation Levels: Resulis of Measurements Taken During 1975-1979, Oak Ridge National Laboratory. ORNL/TM-7343 (November 1981). 


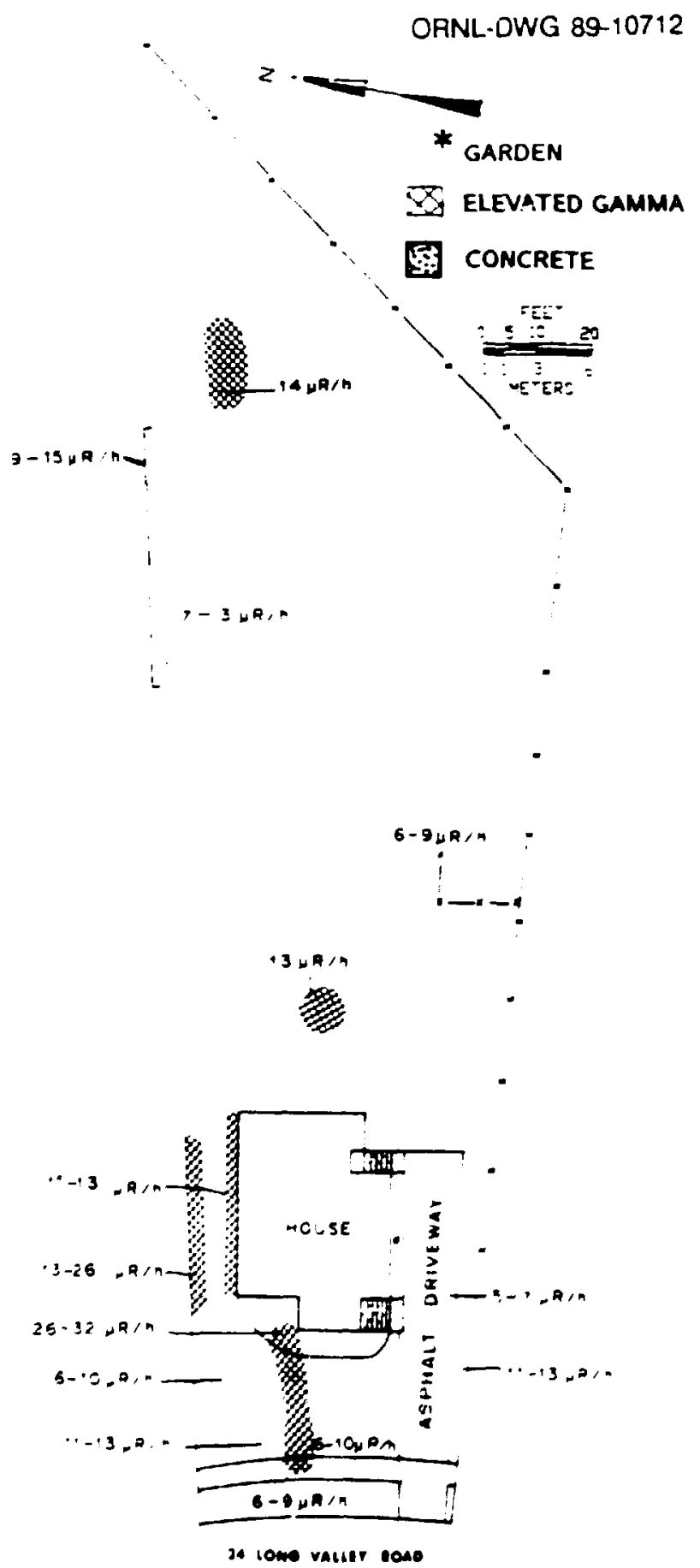

Fig. 1. Ganma radiation levels $(\mu \mathrm{R} / \mathrm{h})$ measured on the surface at 24 Long Valley Road, Lodi, Nen Jersey (LJ048). 
ORNL-DWG 89-10713

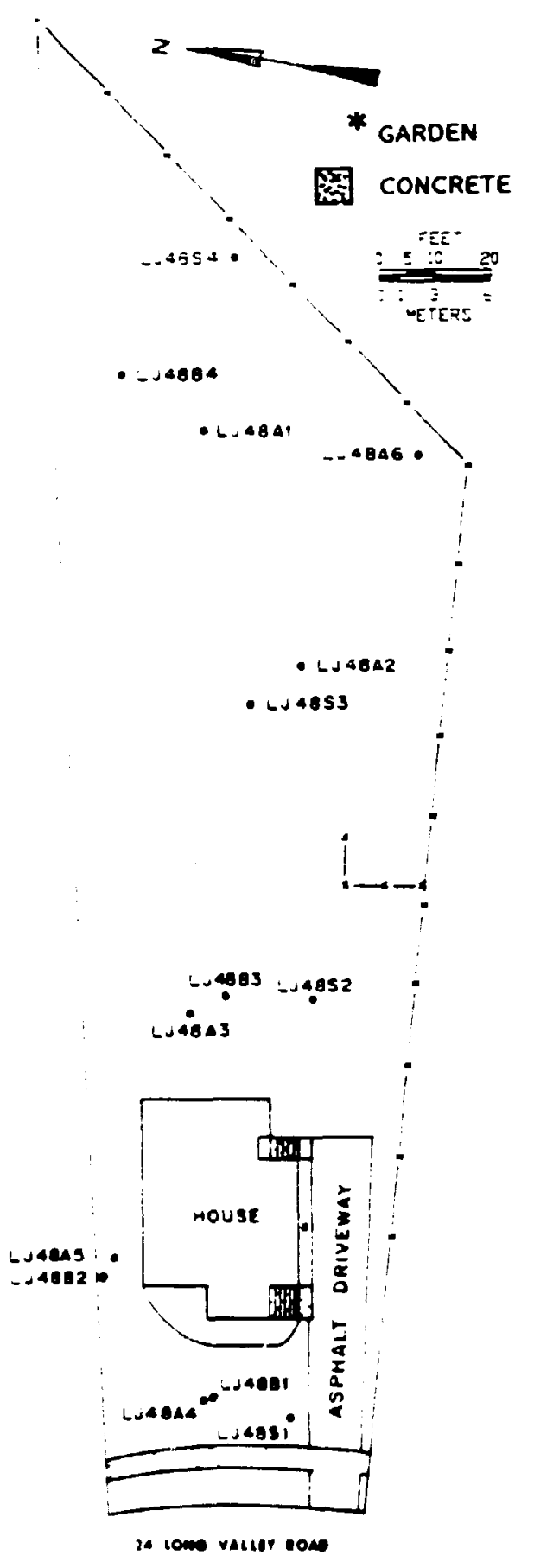

Fig. 2. Diagram showing locations of soil samples taken at 24 Long Valley Road, Lodi, New Jersey (LJ048). 
ORNL-DWG 89-10714

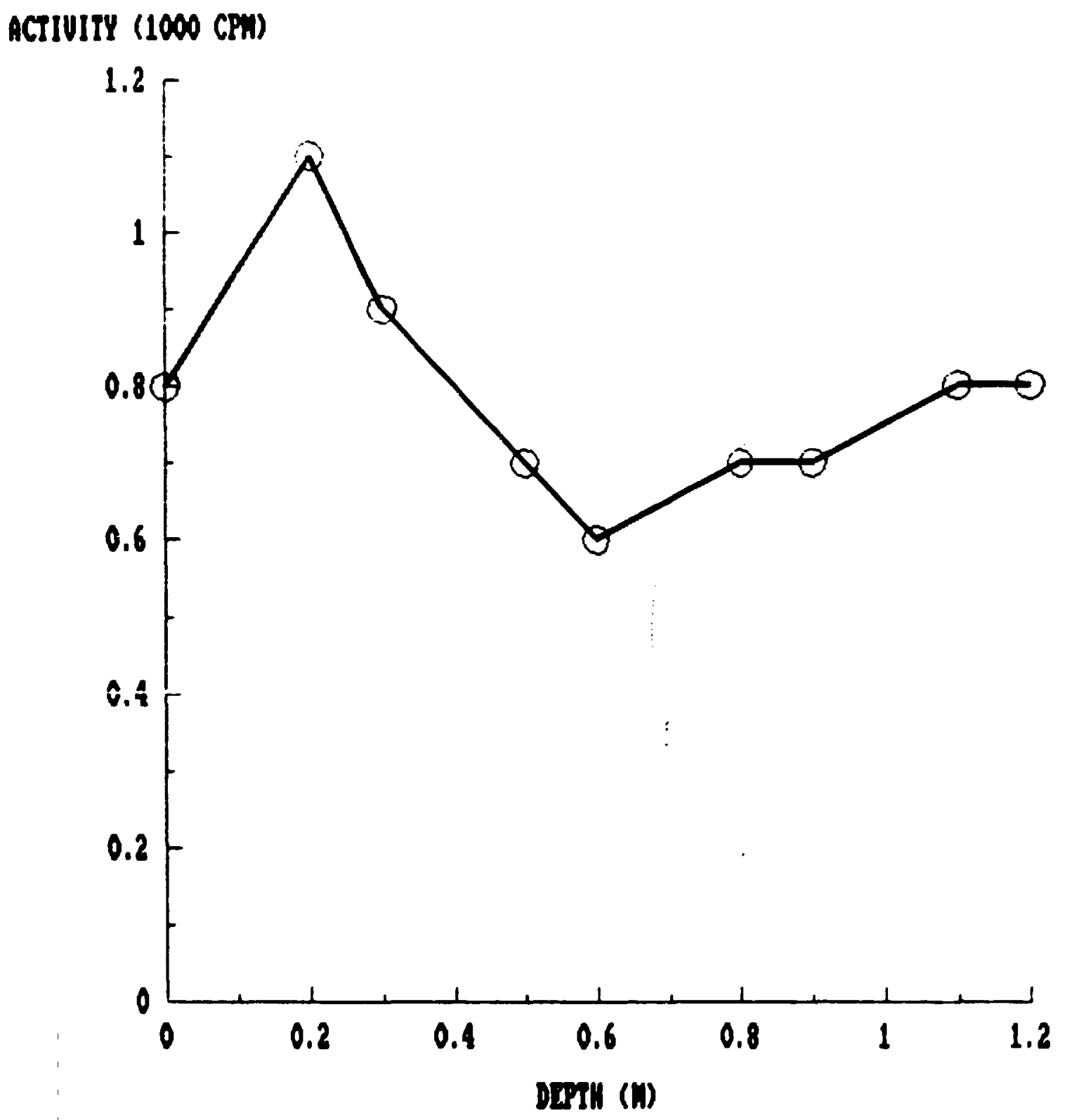

Fi. 3. Gamma profile for anger bole 1 (LJO48A1) at 24 Lome Valley Road, Lod, New Jersey. 
8

ORNL-DWG 89-10715

ACTIUITY (1000 CPN)

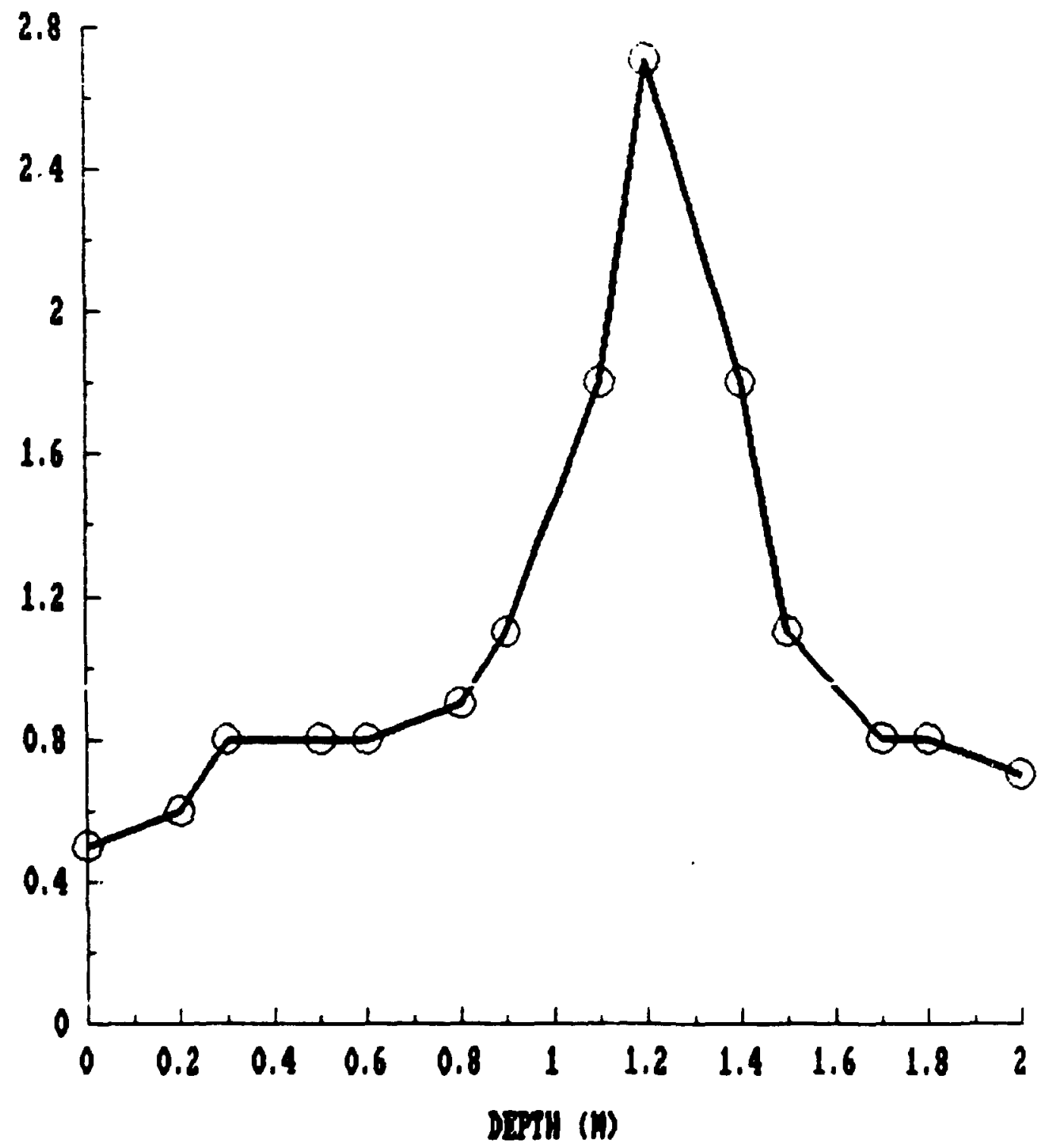

Fie. 4. Gaman profle for anger bole 2 (LJa48A2) at 24 Loes Valley Road, Lodi, New Jersey. 
ORNL-OWG 89-10716

\section{ACTIUITY (1000 CPH)}

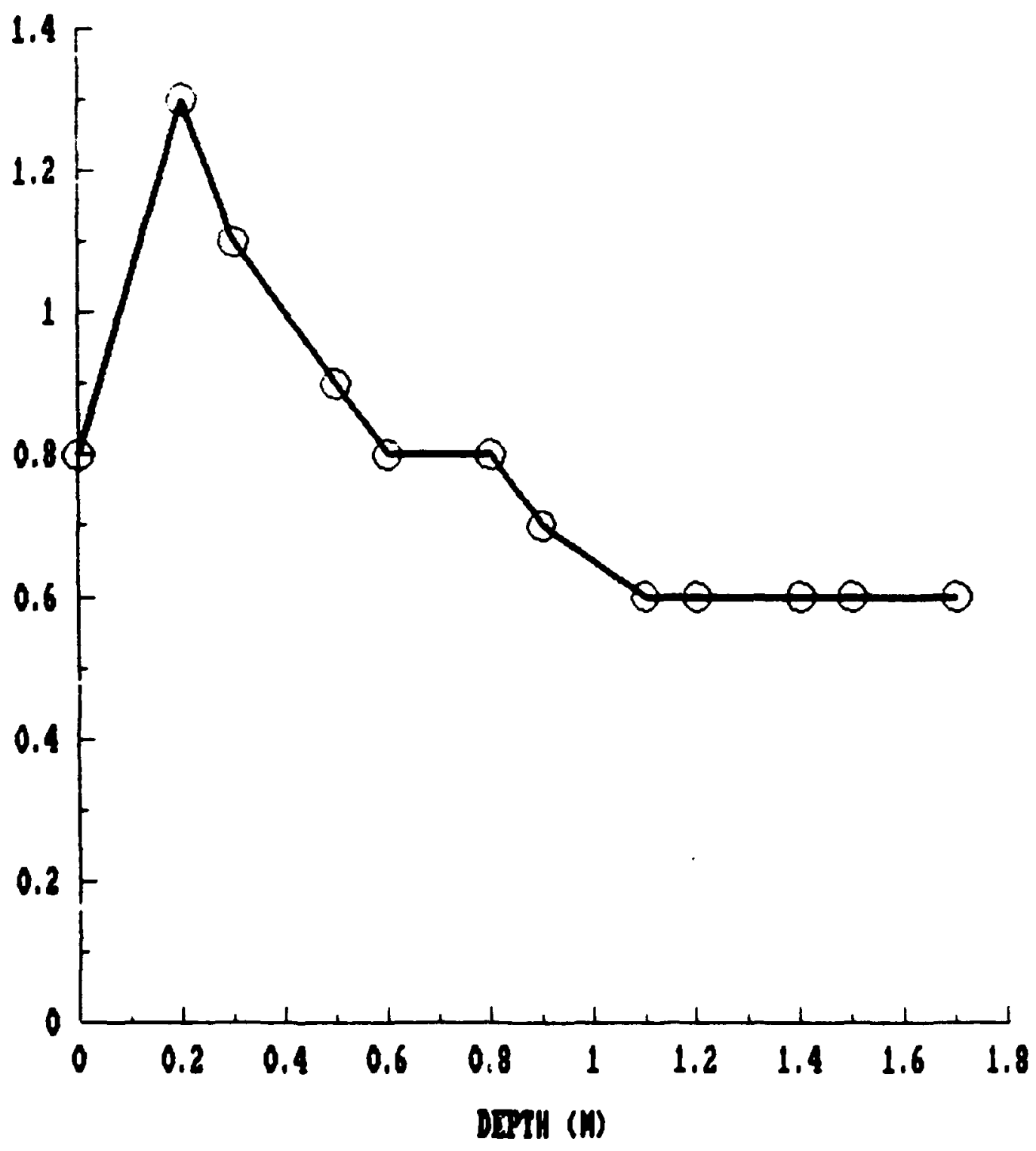

Fig. 5. Gamma profle for anger bole 3 (LJ048A3) at 24 Loag Valley Road, Lod, New Jersey. 
ORNL-DWG 89-10717

\section{ACTIVITY (1000 CPW)}

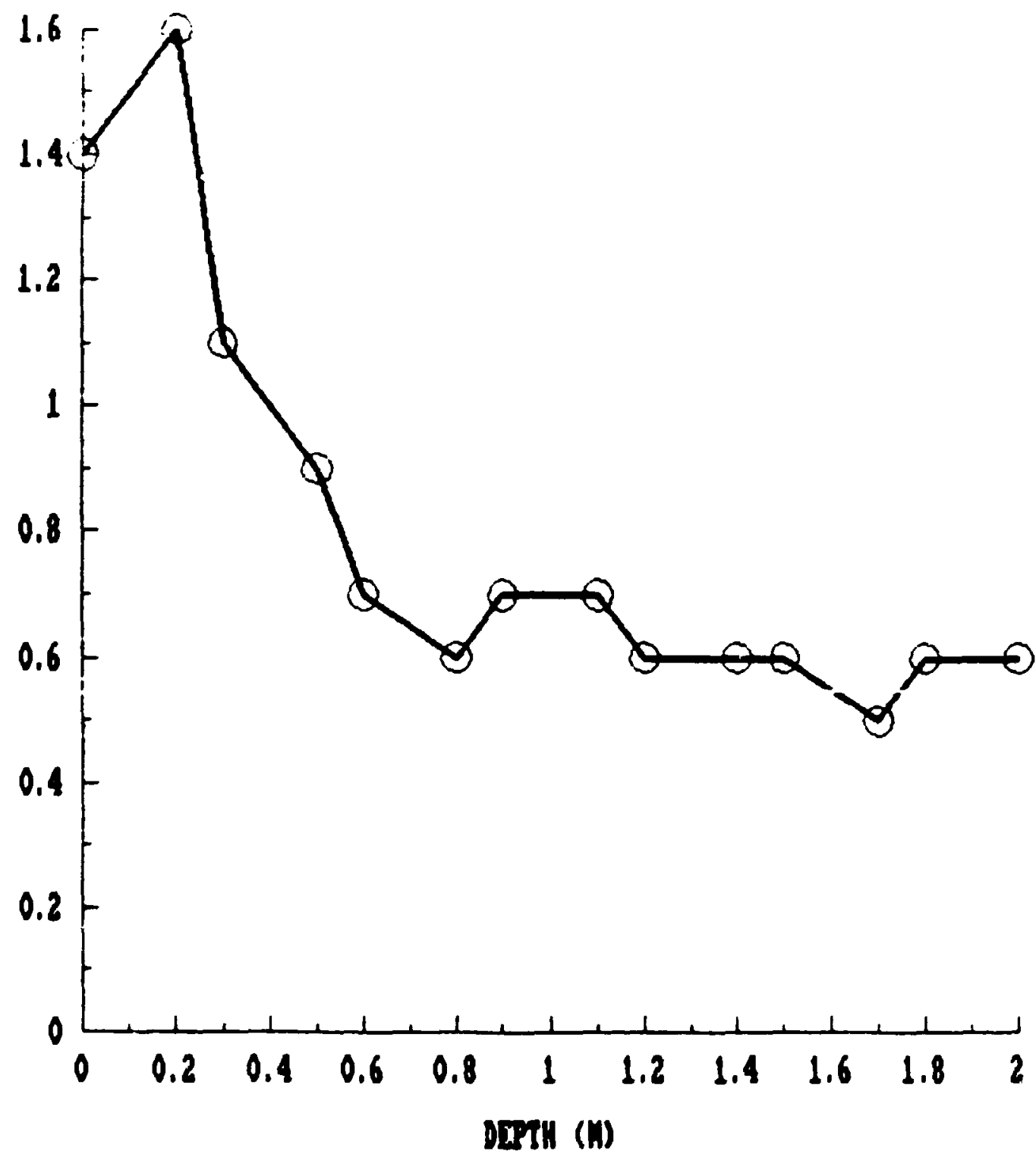
Jersey.

Fig. 6. Gamma profile for anger bole 4 (LJO48A4) at 24 Lomg Valley Road, Lodl, New 


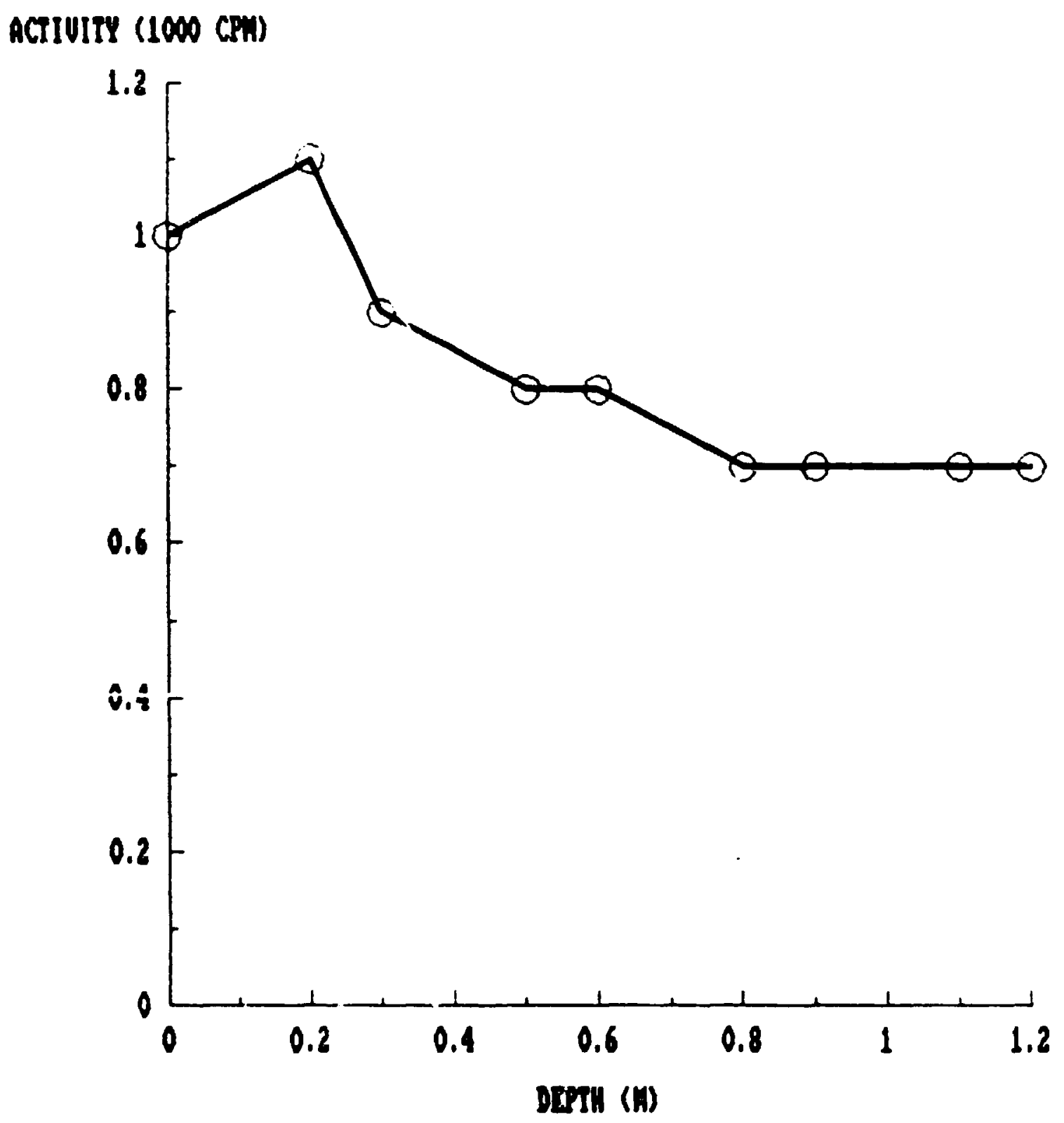

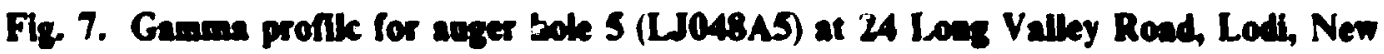
Jersey. 
ORNL-DWG 89-10719

\section{ACTIUITY (1000 CPH)}

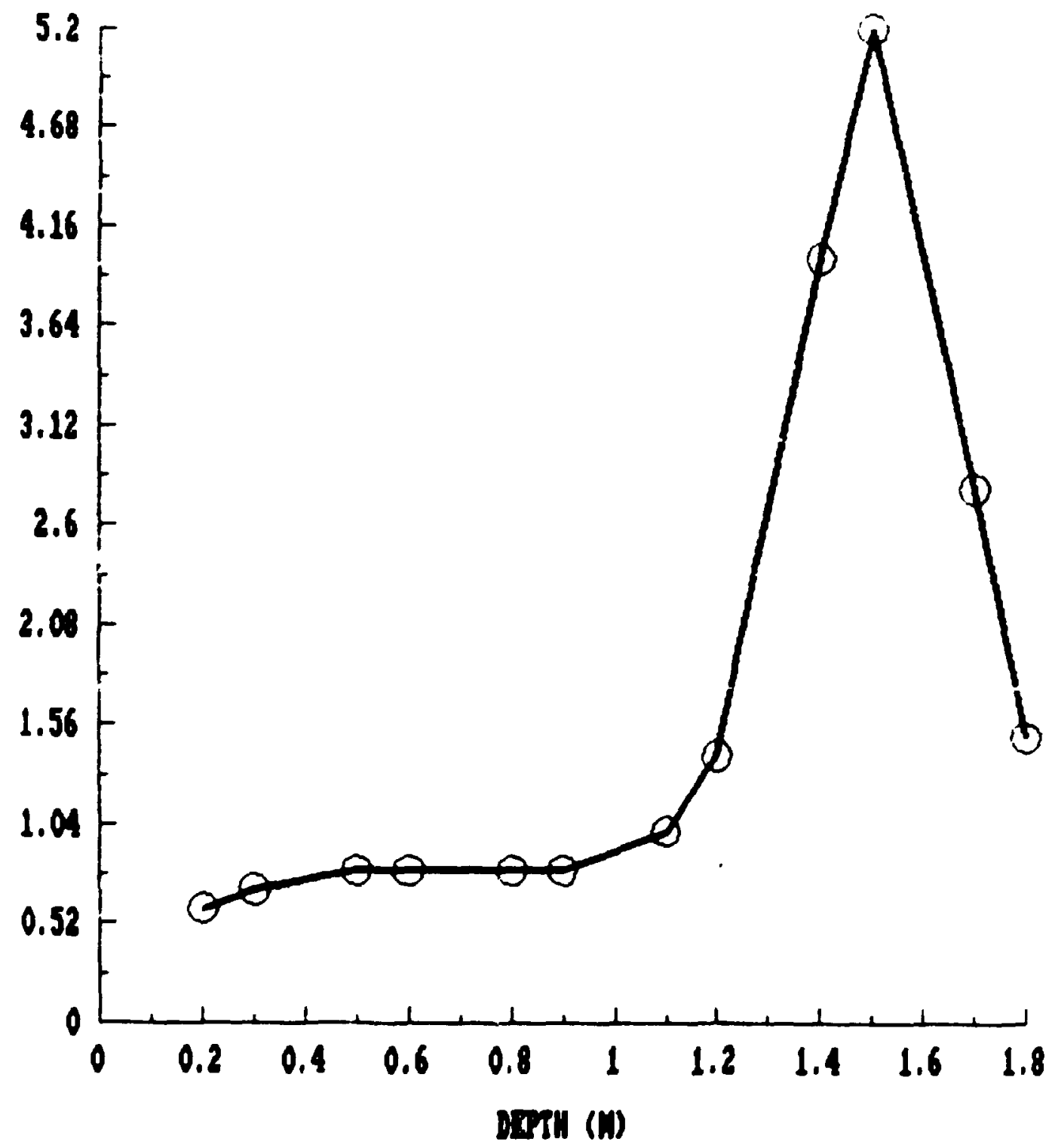

Fig. 8. Ganau proflite for anger bole 6 (LJ048A6) at 24 Lome Valley Road, Lodi, New Jersey. 
Talle 1. Applicalle gildetines for protection against radintione

\begin{tabular}{|c|c|c|}
\hline Mode of exposure & Exposure conditions & Guideline value \\
\hline $\begin{array}{l}\text { Radionuclide } \\
\text { concentrations } \\
\text { in soil }\end{array}$ & $\begin{array}{l}\text { Maximum permissible concen- } \\
\text { tration of the following } \\
\text { radionuclises in soil } \\
\text { above background levels } \\
\text { averaged over } 100 \mathrm{~m}^{2} \text { area } \\
{ }^{232} \mathrm{Th} \\
{ }^{230} \mathrm{Th} \\
228 \mathrm{Ra} \\
{ }^{226} \mathrm{Ra}\end{array}$ & $\begin{array}{l}5 \mathrm{pCi} / \mathrm{g} \text { averaged } \\
\text { over the first } 15 \mathrm{~cm} \\
\text { of scil below the } \\
\text { surface; } 15 \mathrm{pCi} / \mathrm{g} \\
\text { when averaged over } \\
15-\mathrm{cm} \text { thick soil } \\
\text { layers more than } 15 \mathrm{~cm} \\
\text { below the surface }\end{array}$ \\
\hline
\end{tabular}

'Reference 3.

Tabic 2. Backgrom radiation levels for the corthern New Jersey area

\begin{tabular}{cc}
\hline $\begin{array}{c}\text { Type of radiation measurement } \\
\text { or sample }\end{array}$ & $\begin{array}{c}\text { Radiation level or } \\
\text { radionuclide concentration }\end{array}$ \\
\hline $\begin{array}{c}\text { Concentration of radionuclides } \\
\text { in soil (pCi/g) }\end{array}$ & \\
${ }_{232} \mathrm{Th}$ & $0.9^{\star}$ \\
${ }^{238} \mathrm{U}$ & $0.9^{\star}$ \\
${ }^{226} \mathrm{Ra}$ & $0.9^{\star}$ \\
\hline
\end{tabular}

'Reference 4. 
Talke 3. Concentration of rationetides in soil at 24 Lore Valley Road, Lodi, New Jersey (LJ048)

\begin{tabular}{|c|c|c|c|c|}
\hline \multirow{2}{*}{ Sample } & \multirow{2}{*}{$\begin{array}{l}\text { Depth } \\
(\mathrm{cm})\end{array}$} & \multicolumn{3}{|c|}{ Radionuclide concentration ( $\mathrm{pCi} / \mathrm{g}$ ) } \\
\hline & & ${ }^{226} \mathrm{Ra}^{b}$ & ${ }^{232} \mathrm{Th}^{6}$ & ${ }^{238} U^{c}$ \\
\hline \multirow{3}{*}{$\begin{array}{l}\text { S1 } \\
\text { S2 } \\
\text { S3 } \\
\text { S4 }\end{array}$} & & Systematic so & & \\
\hline & $\begin{array}{l}0-15 \\
0-15 \\
0-15 \\
0-15\end{array}$ & $\begin{array}{l}0.64 \pm 0.09 \\
0.60 \pm 0.09 \\
0.74 \pm 0.09 \\
0.91 \pm 0.1\end{array}$ & $\begin{array}{c}1.0 \pm 0.3 \\
0.62 \pm 0.4 \\
0.98 \pm 0.3 \\
1.0 \pm 0.6\end{array}$ & $\begin{array}{l}0.80 \\
0.60 \\
0.76 \\
0.97\end{array}$ \\
\hline & \multicolumn{3}{|c|}{ Biased samplese } & \\
\hline $\begin{array}{l}\text { B।A } \\
\text { B! B }\end{array}$ & $\begin{array}{r}0-15 \\
15-30\end{array}$ & $\begin{array}{l}5.7 \pm 0.7 \\
1.8 \pm 0.2\end{array}$ & $\begin{array}{l}57 \pm 2 \\
13 \pm 2\end{array}$ & $\begin{array}{l}7.8 \\
2.2\end{array}$ \\
\hline $\begin{array}{l}\mathbf{B 2 A} \\
\mathbf{B 2 B} \\
\mathbf{B 2 C}\end{array}$ & $\begin{array}{r}0-15 \\
15-30 \\
30-45\end{array}$ & $\begin{array}{l}2.3 \pm 0.4 \\
0.89 \pm 0.3 \\
0.63 \pm 0.04\end{array}$ & $\begin{array}{ll}15 & \pm 2 \\
2.5 & \pm 0.3 \\
1.3 & \pm 0.3\end{array}$ & $\begin{array}{l}4.3 \\
1.2 \\
0.82\end{array}$ \\
\hline $\begin{array}{l}\mathbf{B} 3 \mathbf{A} \\
\mathbf{B} 3 \mathbf{B} \\
\mathbf{B} 3 \mathbf{C}\end{array}$ & $\begin{array}{r}0-15 \\
15-30 \\
30-45\end{array}$ & $\begin{array}{l}0.80 \pm 0.06 \\
1.7 \pm 0.1 \\
0.77 \pm 0.1\end{array}$ & $\begin{aligned} 2.7 & \pm 0.5 \\
13 & \pm 2 \\
2.8 & \pm 0.1\end{aligned}$ & $\begin{array}{l}0.89 \\
2.2 \\
1.1\end{array}$ \\
\hline $\begin{array}{l}\text { B4A } \\
\text { B4B }\end{array}$ & $\begin{array}{r}0-15 \\
15-30\end{array}$ & $\begin{array}{l}1.1 \pm 0.3 \\
1.0 \pm 0.2\end{array}$ & $\begin{array}{l}3.7 \pm 1 \\
3.5 \pm 1\end{array}$ & $\begin{array}{l}1.6 \\
1.5\end{array}$ \\
\hline \multicolumn{5}{|c|}{ Auger samplest } \\
\hline $\begin{array}{l}\text { AlA } \\
\text { AIB }\end{array}$ & $\begin{array}{c}0-30 \\
75-105\end{array}$ & $\begin{array}{l}1.2 \pm 0.2 \\
0.54 \pm 0.04\end{array}$ & $\begin{array}{c}3.9 \pm 0.3 \\
0.74 \pm 0.2\end{array}$ & $:$ \\
\hline $\begin{array}{l}\mathbf{A} 2 \mathbf{A} \\
\mathbf{A} 2 \mathbf{B}\end{array}$ & $\begin{array}{c}60-90 \\
105-135\end{array}$ & $\begin{array}{c}0.73 \pm 0.1 \\
1.2 \pm 0.1\end{array}$ & $\begin{array}{c}0.84 \pm 0.4 \\
3.3 \pm 0.3\end{array}$ & 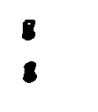 \\
\hline $\begin{array}{l}\text { A3A } \\
\text { A3B }\end{array}$ & $\begin{array}{l}15-45 \\
60-90\end{array}$ & $\begin{array}{l}1.2 \pm 0.09 \\
1.1 \pm 0.05\end{array}$ & $\begin{array}{l}7.0 \pm 1 \\
1.7 \pm 0.4\end{array}$ & 8 \\
\hline $\begin{array}{l}\text { A4A } \\
\text { A4B } \\
A 4 C \\
\text { A4D }\end{array}$ & $\begin{array}{c}0-30 \\
60-90 \\
120-150 \\
150-185\end{array}$ & $\begin{aligned} 2.9 & \pm 0.2 \\
0.78 & \pm 0.08 \\
1.0 & \pm 0.2 \\
1.2 & \pm 0.05\end{aligned}$ & $\begin{array}{cc}25 & \pm 2.6 \\
1.7 & \pm 0.1 \\
0.90 & \pm 0.3 \\
0.76 & \pm 0.3\end{array}$ & : \\
\hline $\begin{array}{l}\text { ASA } \\
\text { ASB }\end{array}$ & $\begin{array}{r}0-30 \\
60-90\end{array}$ & $\begin{array}{c}1.1 \pm 0.05 \\
0.82 \pm 0.06\end{array}$ & $\begin{array}{l}4.4 \pm 0.6 \\
1.2 \pm 0.2\end{array}$ & 8 \\
\hline
\end{tabular}


Talke 3. (contioned)

\begin{tabular}{|c|c|c|c|c|}
\hline \multirow{2}{*}{ Sample } & \multirow{2}{*}{$\begin{array}{c}\text { Depth } \\
\text { (cm) }\end{array}$} & \multicolumn{3}{|c|}{ Radionuclide concentration ( $\mathrm{PCi} / \mathrm{g}$ ) } \\
\hline & & ${ }^{226} \mathrm{Ra}^{\mathrm{b}}$ & ${ }^{232} \mathrm{Th}^{6}$ & ${ }^{238} \mathrm{U}^{\mathrm{c}}$ \\
\hline $\begin{array}{l}\text { A6A } \\
\text { A6B } \\
\text { A6C } \\
\text { A6D }\end{array}$ & $\begin{array}{l}120-135 \\
135-150 \\
150-165 \\
165-185\end{array}$ & $\begin{array}{l}1.1 \pm 0.06 \\
2.4 \pm 0.4 \\
3.1 \pm 0.3 \\
1.3 \pm 0.02\end{array}$ & $\begin{aligned} 5.9 & \pm 1 \\
22 & \pm 2 \\
25 & \pm 2 \\
2.4 & \pm 0.2\end{aligned}$ & : \\
\hline
\end{tabular}

'Locations of soil samples are shown on Fig. 2.

Indicated counting error is at the 95\% conficience level $( \pm 2 \sigma)$. level).

Total analytical error of measurement results is less than $\pm 5 \%$ (95\% confidence

Systematic samples are taken at locations irrespective of gamma exposure.

'Biased samples are taken from areas shown to have elevated gamma exposure rates.

Auger samples are taken from boles drilled to further define the depth and extent of radioactive material. Holes are drilled where the surface may or may not be contaminated.

esample was not analyzed for ${ }^{238} \mathrm{U}$. 